\title{
PROCEDURE MANUAL \\ FOR THE ESTIMATION OF AVERAGE \\ INDOOR RADON-DAUGHTER CONCENTRATIONS \\ USING THE RADON GRAB-SAMPLING METHOD
}

April 1986 
This report was prepared as an account of work sponsored by an agency of the United States Government. Neither the United States Government nor any agency thereof, nor any of their employees, makes any warranty, express or implied, or assumes any legal liability or responsibility for the accuracy, completeness, or usefulness of any information, apparatus, product, or process disclosed in this report, or represents that its use would not infringe privately owned rights. Reference therein to any specific commercial product, process, or service by trade name, trademark, manufacturer, or otherwise, does not necessarily constitute or imply its endorsement, recommendation, or favoring by the United States Government or any agency thereof. The views and opinions of authors expressed herein do not necessarily state or reflect those of the United States Government or any agency thereot.

Printed in the United States of America

Avallable from

National Technical Information Service

U S Department of Commerce

5285 Port Royal Road

Springfield, VA 22161

NTIS price codes

Printed copy $\mathrm{A02}$

Microfiche copy A01

Mary Gerry White, TMC Program Manager Office of Remedial Action and Waste Technology

Larry Ball, Coordinator Grand Junction Projects Office

John R. Duray, Project Manager

Technical Measurements Center 


\section{DISCLAIMER}

This report was prepared as an account of work sponsored by an agency of the United States Government. Neither the United States Government nor any agency Thereof, nor any of their employees, makes any warranty, express or implied, or assumes any legal liability or responsibility for the accuracy, completeness, or usefulness of any information, apparatus, product, or process disclosed, or represents that its use would not infringe privately owned rights. Reference herein to any specific commercial product, process, or service by trade name, trademark, manufacturer, or otherwise does not necessarily constitute or imply its endorsement, recommendation, or favoring by the United States Government or any agency thereof. The views and opinions of authors expressed herein do not necessarily state or reflect those of the United States Government or any agency thereof. 


\section{DISCLAIMER}

Portions of this document may be illegible in electronic image products. Images are produced from the best available original document. 
PROCEDURE MANUAL FOR THE ESTIMATION OF AVERAGE INDOOR RADON-DAUGHTER CONCENTRATIONS

USING THE RADON GRAB-SAMPLING METHOD

J. L. George

GJ $/ \mathrm{TMC}--11$

Technica1 Measurements Center

DE86 012078

Apri1 1986

Prepared for

U.S. Department of Energy

Office of Remedil Action and Waste Technology

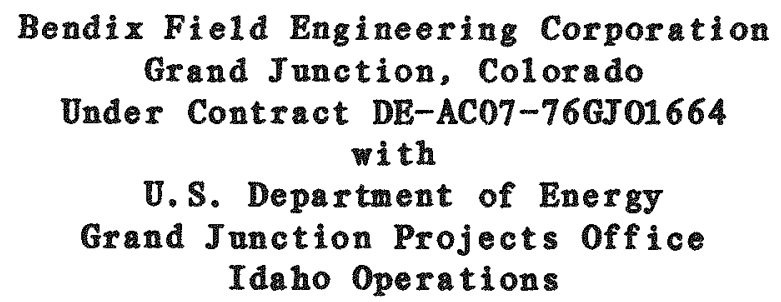


CONTENTS

Page

Summary . . . . . . . . . . . . . . . . . . v

1.0 Introduction . . . . . . . . . . . . . . . . 1

1.1 Purpose and Scope... . . . . . . . . . . . 1

1.2 Radon Grab-Sampling Method.............. . 2

2.0 Instrumentation and Equipment . . . . . . . . . . . . . 3

2.1 Scintillation Cel1s................ 3

2.2 Counting Equipment and Accessories........ . . 8

2.3 Sampling Equipment. . . . . . ......... . 10

3.0 Sample Acquisition and Processing . . . . . . . . . 11

3.1 Barometric-Pressure Effects........... 12

3.2 Additional Precautions . . . . . . . . . . 14

3.3 Background Counting of the Cel1.......... 14

3.4 Sample Collection................. 16

3.5 Sample Counting .. . . . . . . . . . . . 19

3.6 Flushing and Storing the Ce11........... 20

3.7 Data Reduction..................... 20

3.8 Dat Interpretation.................. 21

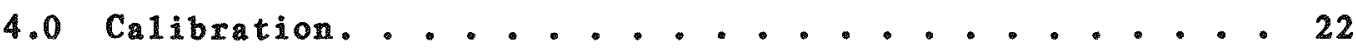

4.1 Counting System Plateau and Daily

Calibration Check................ 22

4.2 Cell Calibration............... 24

4.3 Field Calibration................ 25

5.0 Quality Assurance and Contro1............. 27

5.1 General ................. . 27

5.2 Personne1 and Organization.......... 27

5.3 Procedures................. 29

5.4 Sample and Data Collection........... 29

5.5 Incident Reporting and Corrective Action...... 31

5.6 Recordke eping ............... 31

5.7 Quality-Assurance Audits............. 31

6.0 Acknowledgments.................. 31

7.0 References .................. 32

Appendix A. An Example of a Procedure for Obtaining Radon Grab Measurements Using a Scintillation Ce11 . . A-1 


\section{ILLUSTRATIONS}

Page

Figure 1. Schematic of Scintillation-Cel1

Counting System ............. 4

2. Schematic of Grab Sampling for Flow-Through and

Lucas-Type Scintillation Cel1s ........ 5

3. F1ow-Through-Type Scintillation Cell . . . . 6

4. Relative Apparent-Radon Activity (normalized to $760 \mathrm{mmHg}$ ) Versus Cel1 Pressure ........ 12

5. High-Voltage Counting Curves for Determination of System Plateau and Selection of Operating

High Voltage ............... 23

6. Log of RPISU RDC Versus the Log of Grab Radon for Those Structures with Normal Grab Radon/ RPISU Ratios .............. 28

A-1. Schematic of Baronetric Assembly ........ A-6

\section{TABLES}

Table A-1. Hypothetical Results of Grab Sampling at the Grand Junction Gas Station ......... A-4 


\section{SUMMARY}

The U.S. Department of Energy (DOE) Office of Remedial Action and Waste Technology (formeriy the Division of Remedial Action Projects) established the Technical Measurements Center to provide standardization, calibration, comparability, verification of data, quality assurance, and cost-effectiveness for the measurement requirements of DOE remedial action programs. These programs include the Uranium Mill Tailings Remedial Action (UMTRA) Project, the Surplus Facilities Management Program (SFMP), the Formerly Utilized Sites Remedial Action Program (FUSRAP), and the Grand Junction Remedial Action Program (GJRAP). The Technical Measurements Center (TMC) is located at the DOE Grand Junction, Colorado, Projects office, for which Bendix Field Engineering Corporation is Operating Contractor.

One of the remedial-action measurement needs is the estimation of average indoor radon-daughter concentration. One method for accomplishing such estimations in support of DOE remedial action programs is the radon grab-sampling method. This manual describes procedures for $r a d o n$ grab sampling, with the application specifically directed to the estimation of average indoor radon-daughter concentration (RDC) in highly ventilated structures. This particular application of the measurement method is for cases where $R D C$ estimates derived from long-term integrated measurements under occupied conditions are below the standard and where the structure being evaluated is considered to be highly ventilated. A discussion of the identification of highly ventilated structures and clarification of the conditions under which radon grab sampling should be conducted is provided in the protocol for the Estimation of Average Indoor Radon-Daughter Concentrations [1].

The radon grab-sampling method requires that sampling be conducted under standard maximized conditions. Briefly, the procedure for radon grab sampling involves the following steps:

- Selection of sampling and counting equipment.

- Sample acquisition and processing, including data reduction.

- Calibration of equipment, including provisions to correct for pressure effects when sampling various elevations.

- Incorporation of quality-control and assurance measures.

This manual describes each of the above steps in detail and presents an example of a step-by-step radon grab-sampling procedure using a scintillation cell. 


\subsection{INTRODUCTION}

\subsection{PURPOSE AND SCOPE}

The Technical Measurements Center (TMC) document entitled Protecel for the Estimation of Avergge Indeor Raden-Daughter Concentration [1] discusses methods recommended by the TMC for the estimation of average indoor radon-daughter concentration (RDC) in support of work performed for Department of Energy (DOE) remedial action programs, and suggests guidelines for their use. One such method of estimating indoor RDC is the radon grabsampling method. Among the uses of the radon grab-sampling method is the evaluation of highly ventilated structures (0.g.. gas stations, nurseries, fruit stands, convenience stores, etc.). Briefly, the Protocol states that, in those cases where RDC estimates derived from long-term integrated measurements under occupied conditions are below the standard, and where the structure being evaluated is considered to be highly ventilated, a series of radon measurements should be obtained using the radon grab-sampling method. Radon grab sampling, conducted under standard maximized conditions, is the DOE-approved method recommended for use in such structures since radon grab measurements permit more valid RDC estimations than do long-term integrated measurements obtained under conditions of high ventilation [2]. This is true of the radon $8 \mathrm{rab}$ method despite the fact that it does not meet the reasonable-assurance criterion of estimating average radon-daughter concentration at the 95 percent confidence level.

This manul presents the information and procedures necessary to set up and operate system to obtain radon grab measurements using the scintillation-cell method. The application of the method is specifically directed to the estimation of average indoor RDC in highly ventilatod structures, since this particnlar application is rolatively complex. A discussion of the nncertainties of the resulting RDC estimate is beyond the scope of this mana 1, but can be found in the Protoco1 [1]. The procedures are designed to produce a radon measurement having a coefficient of variation less than 15 percont and a mean bias of no more than 10 percent. Minor deviations from these procedures should be made only if the coefficient of variation and bias of measurement do not exceed the above-stated limits. 


\subsection{RADON GRAB-SAMPLING METHOD}

Radon grab sampling, as described in this manual, refers to the measurement of instantaneous (5-to-10-minute duration), rather than continuous or time-integrated, radon concentrations. The two types of field method for radon grab sampling, use of twofilter chambers, and use of scintillation cells, are described and evaluated below.

\subsubsection{Two-Filter Method}

In the two-filter grab-sampling method, air is drawn through a metal tube which supports a high-efficiency filter at each end. The first filter removes all particulates and radon daughters while allowing radon to pass through the tube. Radium $A$ (RaA or polonium-218), produced by the decay of radon, is collected on the second filter. Immediately after sampling, the second filter is removed and alpha-counted using standard equipment. The radon activity of the air sample is calculated from the alpha counts, the pump-flow rate, calibration factor, and sampling and counting times. A sensitivity of 5 picocuries per liter (pCi/1) is attainable for a $0.5-1$ iter tube (typically of 5-cm diameter), and a sensitivity of $0.1 \mathrm{pCi} / 1$ for a $65-1$ iter tube [3].

1.2.1.1 Advantages of the Two-Filter Method. Inlet filters may be counted simultaneous1y for determination of radon-daughter concentration in working levels (WL).

1.2.1.2 Disadvantages of the Two-Filter Method. Disadvantages of the two-filter method include relatively low count rates, difficulties in maintaining the system calibration, variations in the fraction of RaA deposited on the second filter, possibility of leakage around the first filter, and the inconvenience of taking counting equipment and a high-volume pump to every sampling location.

\subsubsection{Scintil1ation-Ce11 Method}

In the scintillation-cell method, filtered air sample is drawn into and sealed in a cell which has a coating of zinc sulfide phosphor on its interior walls. The cell is counted after a 4-hour delay to allow the short-1ived daughters of radon to reach equilibrium with the radon. The cell is placed in a specialized light-tight housing on top of a photomultipliex (PM) tube. Light flashes emitted by alpha particles striking the phosphor are 
converted by the PM tube into signal pulses and counted with a scaler to determine the radon activity in the air sample.

\subsubsection{Advantages of the Scintillation-Ce11 Method. The}

scintillation-cell method has the advantages of simplicity and improved accuracy and sensitivity (e.g.. $0.1 \mathrm{pCi} / 1$ for a $0.5-$ 1iter cell) as compared with the two-filter method. In addition. on-site equipment needs are minimized. High-volume pumps, for example, are unnecessary: a sma11, 1ightweight pump is adequate. Also, since counting of the sample is delayed, counting equipment can remain in the laboratory.

\subsubsection{Disadvantages of the Scintillation Ce11 Method. There} are several disadvantages associated with the scintillation-cell method. Ce11s must be leak-tested and background count rates must be closely monitored. E1ectrostatic fields can cause variations in the distribution of radon daughters in the cell, thereby affecting the accuracy of count rates. One type of cell is fragile and expensive. See Sections 2.1.1 and 2.1.2 for further discussion.

\subsubsection{Method of Choice}

Based upon a review of the advantages and disadvantages of each method, use of a scintillation cell is the method of choice for conducting radon $g \mathrm{rab}$ sampling in support of DOE remedial action programs and is the method addressed in this procedure manual.

\subsection{INSTRUMENTATION AND EQUIPMENT}

Figure 1 is a schematic of a scintillation-cell counting system; Figure 2 is a schematic showing grab sampling for two types of scintillation cells, flow-through and Lucas-type. Figure 3 shows an actual flow-through cell assembled for grab sampling. The subsections that follow provide brief descriptions of the equipment necessary to acquire radon grab samples using the scintillation-cell method. Information on equipment suppliers is also included where appropriate.

\subsection{SCINTILLATION CELLS}

Two types of scintillation cell are available. The doublevalved flow-through cell is designed for acquiring samples by flowing air through the cell. The single-valved Lucas-type cell 


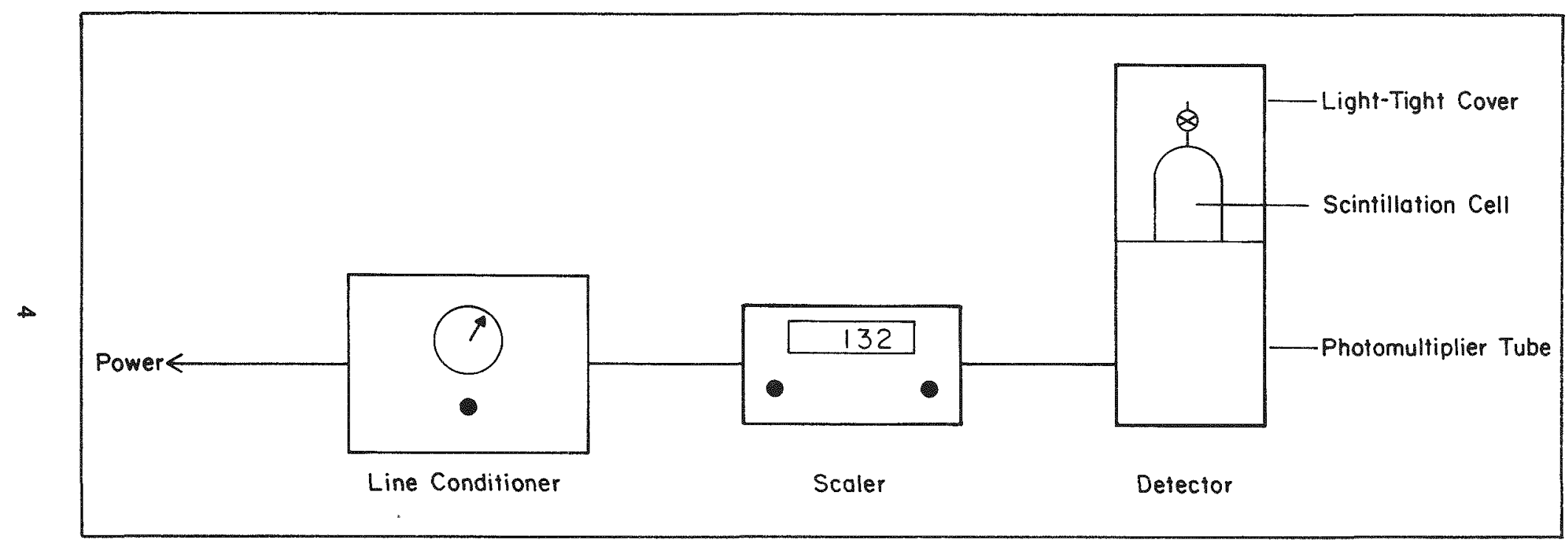

Figure 1. Schematic of Scinti11ation-Ce11 Counting System 


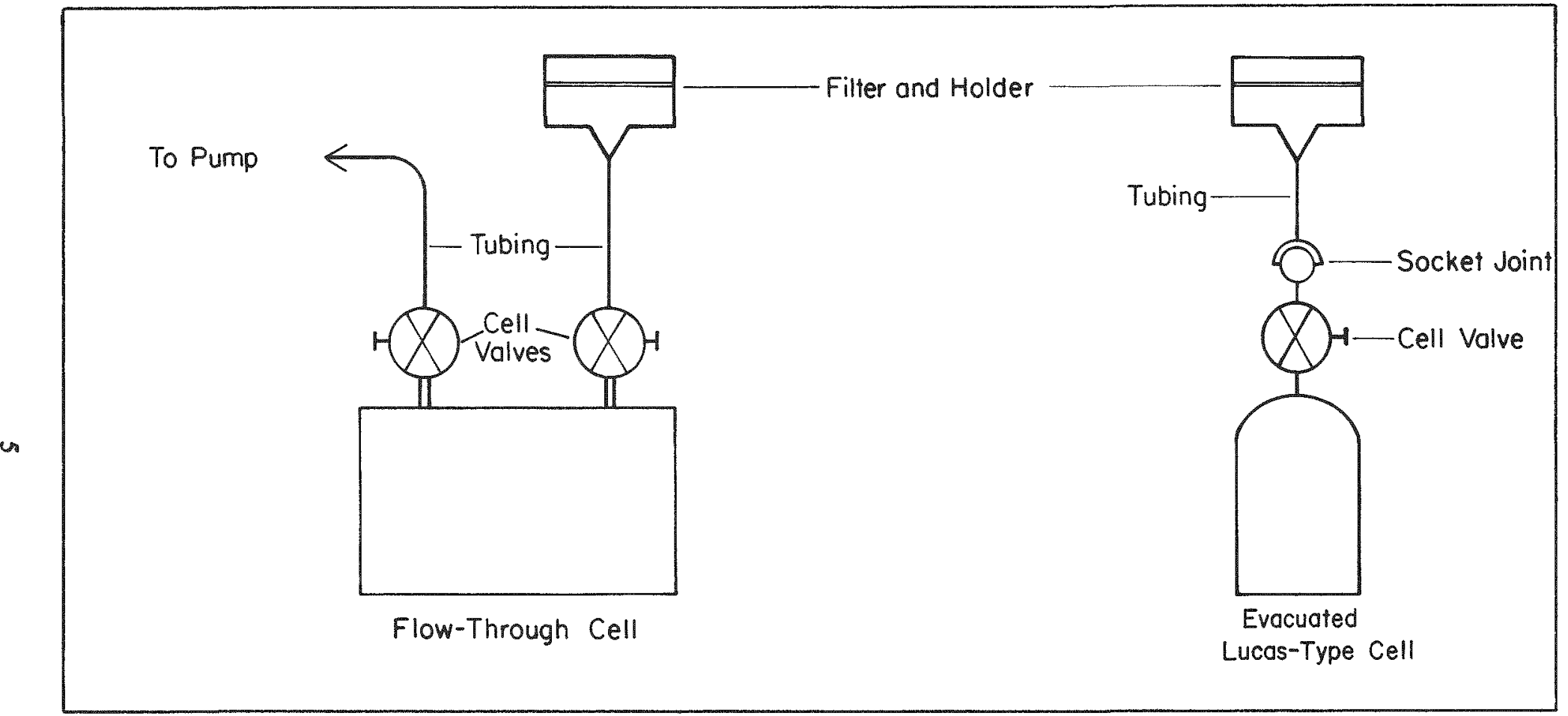

Figure 2. Schematic of Grab Sampling for Flow-Through and Lucas-Type Scinti11ation Cel1s 
REPRODUCED FROM

BEST AVAILABLE COPY

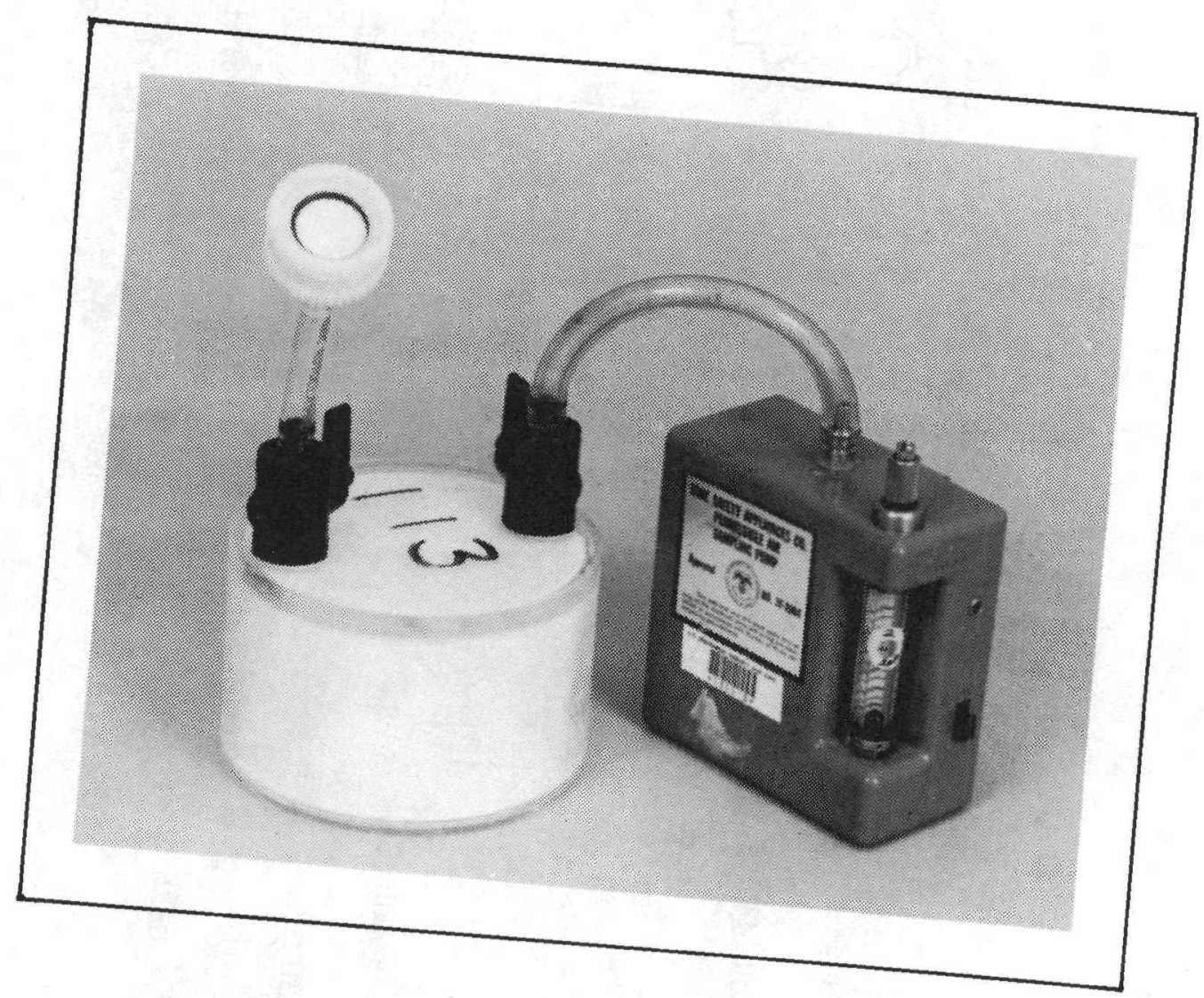

Figure 3. Flow-Through-Type Scintillation Cell 
must be evacuated prior to sampling; sample air fills the cell when the valve is opened. Several manufacturers of these types of cells are named in the following discussions. Those companies not mentioned who also manufacture scintillation cells include Ludlum Measurements. Inc., of Sweetwater. Texas: Pylon Electronic Development Company, Ltd., of Ontario, Canada: and EDA Instruments, Inc., of Toronto, Canada.

\subsubsection{Flow-Through-Type Scinti1lation Ce11s}

Double-valved scintillation cells are commercially available in $0.1-, 0.5-$ and 1.4-1iter volumes from Eberline Instrument Corporation of Santa Fe, New Mexico, with reported sensitivities to radon-222 of 0.59 counts per minute/pCi/1 ( $\mathrm{pm} / \mathrm{pCi} / 1), 2.3$ $\mathrm{cpm} / \mathrm{pCi} / 1$, and $5.5 \mathrm{cpm} / \mathrm{pCi} / 1$, respectively. These cells are based on a design originally proposed by A. George [4] of the Health and Safety Laboratory of the U.S. Energy Research and Development Administration [now the Environmental Measurements Laboratory (EML) of the U.S. Department of Energy]. All three sizes are right cylinders that are manufactured from transparent plastic, equipped with two valves, and coated internally with zinc sulfide phosphor. The bottom plate of the 1.4-1iter cell is not coated in order to improve light collection. Radon does not escape from leak-tested cells or diffuse into the plastic when used for environmental-1evel sampling. Beckman describes a method for making cells from 125-ml Erlenmeyer flasks which are coated internally with zinc sulfide, sealed with a two-hole rubber stopper, and sampled through rubber and metal tubing which is then closed by clamps [.5]. Sensitivities range from 0.5 to $1.0 \mathrm{cpm} / \mathrm{pCi} / 1$. Leakage through the rubber stopper can be a problem; therefore, this cell type is not recommended.

\subsubsection{Elimination of Electrostatic-Field Effects. E1ectro-} static fields can cause variations in the distribution of radon daughters within the scintillation cell, theroby cansing inaccurate count rates and associated results. Electrostaticfield effects can be eliminated by grounding the cathode of the PM tube and coating all internal surfaces of the cell with phosphor [4], by applying an antistatic spray to the cell after sample collection, or by storing the cell in conductive environment during ingrowth ( $0.8 .$. on shelf in metal cabinet).

2.1.1.2 Advantages of Flow-Through Cells. Advantages of these plastic flow-through colls re their relativoly low cost and sufficient ruggedness for routine field use. 


\subsubsection{Lucas-Type Scintillation Cel1s}

Lucas-type cells are dome-topped, metallic or metallized glass shells which are coated internally with zinc sulfide phosphor, and were origina11y designed by H. F. Lucas [6]. The flat bottom surface is transparent. A single valve is located on top of the dome. Electrostatic-field effects can be eliminated by making the cell window electrically conductive or by grounding the cell during sample ingrowth.

2.1.2.1 Disadvantages of Lucas-Type Ce11s. Lucas-type ce11s have sensitivities similar to plastic flow-through cells, but they are more fragile and expensive. Erroneous measurements will result from insufficient cell evacuation or partial loss of vacuum prior to sampling.

2.1.2.2 Advantages of Lucas-Type Ce11s. Lucas-type ce11s have low backgrounds (typically less than $0.2 \mathrm{cpm}$ ), a critical feature when measuring environmental levels of radon. Furthermore, cells that acquire high backgrounds can be decontaminated and recoated with new phosphor for reuse.

\subsubsection{Suppliers of Lucas-Type Ce11s. Rocky Mountain}

Scientific G1ass Blowing Company of Aurora, Colorado, manufactures a 0.1-1iter Lucas-type ce11. The cell body is composed of a rust-resistant nickel alloy and has an electrically conductive quartz-g1ass window. Johnston Laboratories of Cockeysville, Maryland, is also a supplier. H. F. Lucas, $J_{r}$. describes how to assemble single-valved cel1s from 1-1iter narrow-necked bottles sealed with a rubber stopper [7]. Lucas reports the loss of radon through the rubber stopper, and for this reason this bottle-type cell is not recommended.

\subsection{COUNTING EQUIPMENT AND ACCES SORIES}

The equipment items described in Subsections 2.2 .1 through 2.2 .4 are suggested for counting scintillation cells. The soaler and photomultiplier tube must remain together as one unit.

\subsubsection{Scaler and High-Voltage Supply}

The digital scaler should feature a convenient, legible display and adjustable high voltage. A variable timex with thumbweel or key-pad settings offers much more flexibility than a timer with limited preset intervals. Scalers are available in both rackmountable and stand-alone configurations from a large number of 
manufacturers, including Eberline Instrument Corporation of Santa Fe, New Mexico, and Ladlum Measurements, Inc., of Sweetwater. Texas.

\section{2 .2 Detecter}

A photomultiplier (PM) tube is used with a scaler and scintillation cell for alpha scintillation counting. The light-tight cover on the PM tube should be large enough to accommodate the largest scintillation cell used. A high-voltage safety switch that opens automatically when the cover is removed helps prevent damage to the PM tube. The PM tube should be at least 2 inches in diameter, upward facing, and coupled to a preamplifier. The tube's dark current should produce less than $0.1 \mathrm{cpm}$ at the selected operating high voltage. The diameter of the tube should be the minimum size needed to match the scintillation cell. This latter specification is recommended since the number of spurious pulses generated by thermionic electrons emitted spontaneously by the photocathode is proportional to the area of the photocathode. Variations in the thickness of the photocathode are more common in large-diameter tubes and cause changes in sensitivity [8].

If the photocathode needs to be grounded to eliminate electrostatic-field effects, a detector featuring positive high voltage (negative ground) should be used. The low energy of the electrons traveling from stage to stage within a PM tube makes their trajectories sensitive to external electromagnetic fields. Mu-metal shielding can be, incorporated around the $P M$ tube to minimize this effect.

\section{2 .3 Line Conditionex}

Since line-frequency and voltage fluctuations can cause generation of spurious counts and variation in counter efficiency, a line conditioner or isolation transformer is essential. Battery operation of the counting system is another way to circumvent these problems.

\section{2 .4 Accessories}

Other recommended counting-equipment items include a plated alpha source, zinc sulfide coated mylar screens 1 arge enough to accommodate the source, and tweezers for handing screens and sources. The alternative is to use a sealed scintillation cell that contains radium-226 in equilibrium with its daughters. In either 
case, the alpha source should have activity low enough to avoid pulse-pair resolution problems but high enough to produce acceptable statistics over short counting intervals.

Standards having 1000 to $2000 \mathrm{cpm}$ at 25 percent of gross $4-\mathrm{pi}$ efficiency (i.e., 4000 to 8000 disintegrations per minute) are acceptable [5]. An interval timer is also a useful accessory.

\subsection{SAMPLING EQUIPMENT}

Sampling-equipment needs will vary depending upon the type of scintillation cel1 used, either Lacas-type or flow-through.

\subsubsection{Vacuum Pump}

A vacuum pump is needed to evacuate Lucas-type ce11s to 500 microns. The vacuum should be measured with a gange that presents readings in microns so that all cells can be evacuated to the same pressure. The vacuum pump used in the barometric assembly (see Section 2.3.3) may be used for this application as well.

\subsubsection{Sample Pump}

A portable, low-volume air pump is needed for sampling with either type of sointillation cell. Any sample pump that can deliver 1 to 2 1iters per minute $(1 \mathrm{pm})$ is acceptable; a batteryoperated personal monitoring pump is suitable. The pump (or a squeeze bulb) is used to replace residual air with sample air in the filter-holder assembly prior to attaching the assembly to an evacuated Lucas-type ce11. The pump is also used to pull sample air through a flow-through cell. The flow rate of the pump should be calibrated to ensure that enough air passes through a flow-through cell to obtain a representative air sample. The pump must be calibrated in the configuration in which it will be used during sampling, i.e., with the filter, filter holder, and same lengths of tubing in place. Beckman [5] outlines a procedure for pump calibration.

\subsubsection{Barometxic Assemb1y}

Because of the effect of barometric pressure on alpha counting (see Section 3.0), samples should be counted at a pressure for which the cell sensitivity is known. One acceptable method is to bring the scintillation cell to a standard pressure (monitored 
with a barometer which can be read to the nearest mmHg) using bottled, aged air prior to counting. Standard air cylinders and regulators are used, but the cylinders must age at least 30 days after filling. This delay of eight half-lives allows almost all of the radon in the bottled air to decay. However, any radium contained in the cylinder walls will generate radon. The amonnt is usually negligible; but in any case a correction can be applied to compensate for this quantity when necessary [7]. A vacuum pump is used to evacuate all lines before filling the barometric assembly with aged air.

In the event that the scintillation cell has been calibrated for the various pressures at which samples are collected, the barometric assembly is not required.

\section{3 .4 Accessories}

A high-efficiency filter and appropriate filter holder should be used to prevent radioactive contaminants from entering the scintillation cel1. An accurate timepiece is needed to time flowthrough samples and determine the time at which a sample is co1lected. The timepiece should indicate an elapsed time interval (with 99 percent accuracy) and the actual time ( \pm 5 minutes). Antistatic spray is applied to plastic flow-through cells after sample collection to prevent buildup of static charge. Miscellaneous short pieces of rubber tubing are used to connect the filter holder to the ce11; for Lucas-type cells, an adapter is required to join the tubing to the cell.

\subsection{SAMPLE ACQUISITION AND PROCESSING}

Collection of reliable data requires careful adherence to a standard procedure. Proper methodology is especially important when using the counting system. The scaler and PM tube, for example, should stay together as one unit. A plateau curve should be obtained for each counting system to determine the proper operating high voltage, and a check source should be counted each day before a counting system is used to verify the system's reliability (see Section 4.1). Power to the scaler should be left on at all times to ensure stability. If the PM tube does not have an automatic cutoff switch, the high-voltage (HV) cable between the PM tube and the scaler should be disconnected each time the light-tight cover is removed, rather than turning off the scaler power. An uncovered PM tube should not be exposed to excessive incident 1 ight (especially fluorescent 
light), even when no voltage is applied, becanse such exposure causes a temporary increase (typical1y less than 1 minute in duration) in dark current [8].

\subsection{BAROMETRIC-PRESSURE EFFECTS}

Several precations are suggested with respect to the use of the scintillation ce11. The barometric pressure at which a cell is counted is important. Air density affects the path length of an alpha particle and hence the apparent sensitivity of a cell.

\subsubsection{Investigation of Barometric-Pressure Effects}

To investigate barometric-pressure effects, evacuated cells were filled to $400 \mathrm{mmHg}$ from an air sampling bag containing radon. After a 4-hour delay the cells were then counted at $400 \mathrm{~mm} H$ and at several other pressures by pressurizing the cell with aged air. The counts were corrected back to the time of fill. To check for possible bias caused by diffusion of radon from the cell during the pressurization process, the procedure was repeated in reverse. Evacuated cells were filled to ambient pressure from the bag. The cells were counted, partially evacuated, and set aside for 4 hours to allow equilibrium to be reestablished between radon and its daughters; the cells were then recounted. Results were corrected for the evacuated fraction of radon and were also corrected back to the time of fill. Both sets of results were normalized to the apparent activity at $760 \mathrm{mmHg}$ and plotted. (Diffusion of radon from the cell was also investigated by opening a radon-filled cell to the aged-air line. No loss of radon from the cell was detected even after 30 minutes, a time period considerably longer than this step of the procedure requires.)

\subsubsection{Data Interpretation}

Figure 4 presents the plot of relative apparent-radon activity versus cell pressure. These data were acquired to verify the existence of a pressure effect on radon activity, not to quantify the effect precisely. The data are not sufficiently detailed to mathematically determine a pressure correction. The regression 1ine (Figure 4) indicates that a cell that had been calibrated at sea level and used to count ample collected at Grand Junction, Colorado ( 1370 meters above sea leve1, with a barometric pressure of $640 \mathrm{mmHg}$ ). Will overestimate the apparent-radon activity of the sample by approximately 9 percent. 


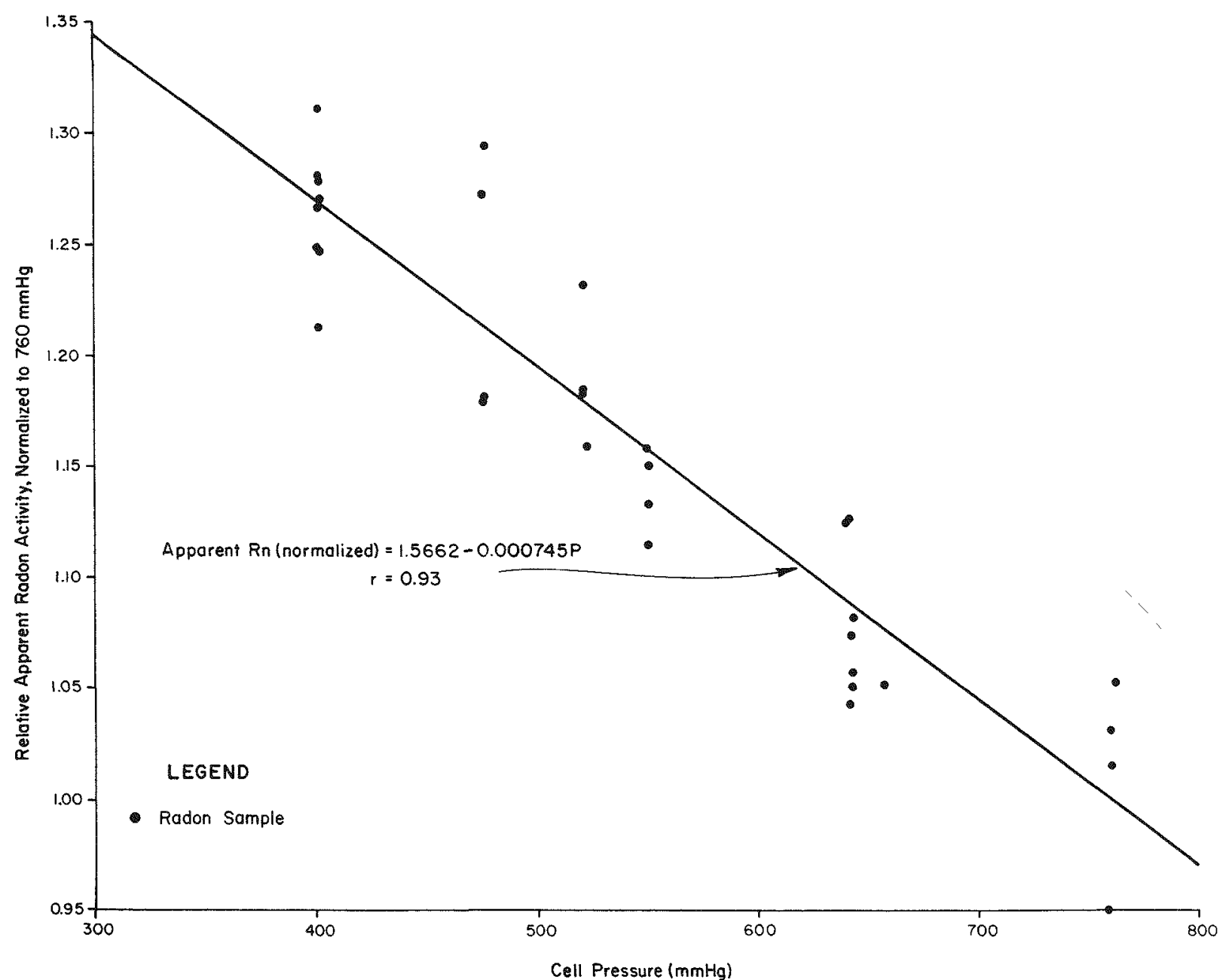

Figure 4. Relative Apparent-Radon Activity (normalized to $760 \mathrm{mmHg}$ ) Versus Cel1 Pressure 


\subsubsection{Corrections for Barometric-Pressure Effects}

Corrections should be applied to compensate for the effect of barometric pressure. One method is to select a standard pressurc for calibration and field-measurement counting that is higher than the pressure at which any sample will ever be collected. The cell can be pressurized immediately before counting without disrupting equilibrium, provided that the radon activity of the bottled a ir is negligible; this procedure is described in Appendix A. Alternatively, the cell can be calibrated at the various pressures that will be encountered during sampling. The effect of humidity on the apparent activity of the samples is small compared with the effect of pressure; air density varies less than 1 percent over the range of 10 to 90 percent relative humidity, at $20^{\circ} \mathrm{C}, 760 \mathrm{mmlig}$.

\subsection{ADDITIONAL PRECAUTIONS}

If samples are collected and counted at widely differing temperatures, a volumetric correction may be necessary. The determination of a separate cell sensitivity is necessary for each counting system with which a scintillation cel1 will be counted. Also, the cell should not be exposed to fluorescent light prior to its placement in the counting system; this precaution will minimize 1 ight-induced scintillations.

A potential source of error in radon grab sampling arises from the need to adjust the times recorded for sample collection and counting. This error can be avoided by ensuring that all laboratory and field timepieces are synchronized to within 5 minutes. For synchronization purposes, a reliable source that can be checked by phone should be used, such as Bell Telephone Time and Temperature or a National Bureau of Standards (NBS) recording. A recording of the current coordinated Universal Time may be accessed by calling 303/499-7111.

Finally, cells should be leak-tested prior to calibration to ensure determination of accurate sensitivities. Lucas-type cel1s that are used routinely should be leak-tested weekly. Cells that cannot hold at least a 500-micron vacuum should not be used until the leak is fixed.

\subsection{BACKGROUND COUNTING OF THE CELL}

Before each use of a scintillation cell to collect a sample, its background count rate should be determined. If a cel1 has 
recently held a radon sample, it should be flushed (see Section $3.6)$ and allowed to stabilize for approximately 1 day ithout a radon sample before background counting, to allow short-1ived radon daughters from the previous sample to decay. The same counting system should be used to count both the background and the sample. Verify the correct operation of the counting system by running the check source as outlined in Section 4.1 , unless this procedure has already been performed earlier that day.

The cell background should be counted at the same pressure at which the sample will be counted. A cell should never be background counted while under vacuum; the resulting counts would be too high. See Appendix A, Section A.6, for the steps involved in pressurizing a cell.

\subsubsection{Procedure for Background Connting of a $\mathrm{Ce} 11$}

Once correct operation of the counting system has been verified and the cell has been properly pressurized, background counts should be obtained in the following manner:

1. Center the scintillation cell over the PM tube, replace the 1 ight-tight cover, and wit 2 minutes (or long enough for 1 ight-induced scintillations to decay and dark current to stabilize) before starting the first background count interval.

2. Count each cell three.times, using counting intervals of the same length as will be used when counting the sample: three 10-minute intervals are usually appropriate.

3. Record the date, counting-system number, check-source counts, cell number, and background counts. Reject any count intervals that are obviously erroneous or that differ from the mean of the other two count intervals by more than the square root of two times their mean. (Note: Erroneous counts may be traced to noise caused by electromagnetic fields induced by such factors as turning a light on or off or plugging in a calculator, by atmospheric electrical discharges such as 1 ightning or precipitation static, or by line pulses; they have no relationship to background activity.)

4. If any counts are rejected, continue counting until three valid background count intervals are obtained. 
5. Remove the cell from the counting system. If the cell has been pressurized, return the cell to ambient pressure by quickly opening and closing a valve.

\subsubsection{Monitoring Background Count Rates of Ce11s}

Background count rates of cells should be closely monitored. The background values will vary considerably from counting system to counting system, but for low-level work they should not exceed $0.2 \mathrm{cpm}$ for Lucas-type cells and $3 \mathrm{cpm}$ for flow-through-type cells. Cells with higher background values should be reserved for work involving high-1evel samples. Lucas-type cells with high background values can be decontaminated, recoated with phosphor, and reused after calibration.

\subsection{SAMPLE COLLECTION}

The radon grab-sampling method is used to obtain two evaluations of a highly ventilated structure on two different days. At most, only one evaluation should be performed during the months of April through September.

\subsubsection{Standard Sampling Conditions}

The validity of the grab-sampling method when used for radon measurement in highly ventilated structures depends on the establishment of standard sampling conditions at each structure to be evaluated. Many sets of standard conditions exist that could be selected for grab sampling. The conditions listed below are intended to create standardized, reproducible conditions that are reasonable and achievable. These conditions are of ten referred to as standard 'maximized' conditions, al though the radon levels in a structure can be increased further by imposing other sets of conditions .

3.4.1.1 Structure Conditiens. The following conditions should be established and maintained for a minimum of 12 hours prior to obtaining the radon grab samples:

- All doors and windows closed.

- A11 ventilation systems turned of

- Surface winds less than 10 miles per hour. 
- Stable atmospheric pressure $(\Delta \mathrm{P} \leq 4 \mathrm{mmHg})$.

- Building unoccupied (if possible).

The ventilation rate is minimized by keping all doors and windows closed, all ventilation systems turned of $f$ and the structure unoccupied. However, some compromises may be necessary. To avoid vacating a house, for example, arrangements should be made to collect a sample just as the household awakens in the morning. It is recommended that the time of $s$ ample collection be standardized between $6: 00$ and 8:00 a.m., not only to minimize inconvenience to the household, but also because indoor radon 1 evels will increase and decrease on a diurnal cycle, even in a 'sealed' structure. By sampling at a standardized time of day, the samples will all be taken on the same relative portion of the diurnal-cycle curve. Systematic variations from structure to structure will be minimized.

The effects of human activity can be kept within tolerable limits by keeping all doors and windows closed and the heat turned down all night, and by delaying the use of furnaces and/or wood stoves until after the sample has been collected. Although an electrostatic precipitator will significantly reduce the radon-daughter concentration, it will not affect the radon concentration in the structure: therefore, its use does not have to be controlled. The use of humidifiers does not have to be controlled because of the minimal effects of humidity on a radon sample (see Section $3.1 .3)$.

3.4.1.2 Meteorelogic Conditions. Meteorologic conditions prior to sampling should be closely monitored. Ideally, the barometer should be steady and surface winds should be less than 10 miles per hour during the 12 hours prior to sampling. These conditions, however, will generally be difficult to meet. Atmospheric pressure, to be acceptable, should vary no more than $4 \mathrm{mmHg}$ in the 12-hour period prior to sampling, and no more than $1 \mathrm{mmlig}$ in any 1 hour during this period. The standardization process outlined above should not be initiated if a high-or low-pressure system is known to be approaching. Meteorologic conditions should be stabilized before notifying the occupants of the structure to shat down the ventilation systems for the night. A record should be maintained of the beginning, ending, and range of wind speed and barometric pressure during the 12-hour period prior to sample collection. 


\subsubsection{Samp1e P1anning}

Before leaving the 1aboratory to collect samples, the necessary sampling equipment and accessories should be assembled; these include ce11s, filters, filter holders, sample pump, antistatic spray, and notebooks. Lucas-type cells should be evacuated in the laboratory to a uniform pressure (e.g., 500 microns). The cells should be handled and packed carefully to minimize the chance of a valve being opened accidentally.

Sampling locations within each structure should be selected as prescribed in the Protocol for the Estimation of Average Indoor Radon-Daughter Concentrations [1]. All samples should be filtered to remove radioactive particulates, including radon daughters. This prevents contamination of the cell and helps maintain a low cell background level by minimizing the buildup of al pha emitters. Collection of duplicate samples is recommended. Filters may be reused many times and left in place in the holders, provided the filters are not damaged. Alternatively, filters may be counted by any one of the standard radon-daughter counting methods [9], if the sample pump has been calibrated.

\subsubsection{Lucas-Type Ce11 Sampling}

The following procedure describes the collection of a sample using a Lucas-type ce11:

1. Remove the cell from the packing box and verify that the valve has not been turned from its fully closed position.

2. Place a filter on the support screen of a filter holder. Replace the top section of the holder and attach a short piece of tubing (approximately $10 \mathrm{~cm}$ in $1 \mathrm{ength}$ ) to the fitting on the screen side of the holder.

3. Connect the filter assembly to the pump with a short piece of tubing (about $15 \mathrm{~cm}$ in 1 ength). Pump room air through the filter to ensure that al1 air entering the ce11 is representative of this sampling location and does not include any air remaining in the tubing from a previous location.

4. Attach the filter assembly to the cell using a clamp and a socket joint. Open the valve for 10 seconds to collect the sample, and record the time of fill.

5. Repack the cell carefully. 


\subsubsection{F1 ow-Through Cel1 Sampling}

To collect a sample using a flow-through cell, follow the procedure presented below:

1. Assemble the filter holder as detailed above for the Lucastype cell.

2. Using rubber tubing, connect the filter holder ta one cell valve and connect the pump inlet to the other valve.

3. Open both cell valves; start the pump and the stopwatch. Allow time for at least ten air exchanges in the ce11, calculated from the calibrated flow rate of the pump and the cell vol ume.

4. Turn of the pump and close the cell valves. Record the time of $f i 11$ as the time at which the pump is turned of $f$.

5. Wipe the cell with antistatic spray before repacking.

\subsubsection{Data Records}

Record all pertinent sampling information, including date collected, location of sample, cell used, time of fill, operator name, ventilation conditions within the structure prior to sampling, and miscellaneous notes on weather conditions.

\subsection{SAMPLE COUNTING}

A 4-hour delay is recommended between the time a cell is filled with the sample and the time a cell is counted to allow radon and its short-1ived daughters to reach equilibrium. This eliminates the need to correct for assumptions and errors that result from counting on the rising portion of the ingrowth curve. During ingrowth, the cell should be stored in a conductive environment to eliminate electrostatic-field effects.

\subsubsection{Procedure for Sample Counting}

Sample counting should be conducted in the following manner:

1. Run the check source on the counting system as described in Section 4.1. Bring the cell to pressure if necessary. 
2. Center the cell over the PM tube, replace the light-tight cover, and wait 2 mintes before starting the count. Tenminute count intervals are suggested for $0.5-1$ iter cells to produce 5 percent counting statistics for environmental levels of radon.

3. Record the start time. Record the total counts after the preset count interval: immediately start the count sequence again.

4. Repeat until three consecutive counts have been acquired. If one of these counts is rejected because of obvious noise interference, continue counting until three valid, successive counts are obtained.

Another method is to count the cell once until 10,000 counts are accumulated (for one percent statistical precision), and record the beginning and ending time of the count period. However, if the counting system is programmed to acquire 10.000 counts automatical1y, erroneous conts due to noise will be more difficult to detect and correct.

\subsection{FLUSHING AND STORING THE CELL}

After the samples are counted, the scintillation cell should be flushed with filtered, bottled nitrogen or aged air. To flush flow-through cells, open both valves and flow the flush gas through the cell at about $21 \mathrm{pm}$. Allow time for ten volume exchanges. Several cells may be flushed in series, provided the flush time is ajusted for the total volume of the series of cells. Close the cell valves and store at ambient pressure. For Lucas-type cells, evacuate the cell and fill with flush gas three times. Fill the last time to ambient pressure, and store with the valve closed.

Cel1s can usual1y be reused and background counted again after sitting overnight, by allowing time for short-1ived radon daughters to decay.

\subsection{DATA REDUCTION}

The radon activity of the sample is calculated using the equation

$$
R n_{0}=\frac{\lambda\left(C_{g}-C_{b}\right)}{Y\left(e^{-\lambda t_{1}}-e^{-\lambda t_{2}}\right)}
$$


where $\mathrm{Rn}_{0}$ is radon activity at $t$ time of sample collection, in $\mathrm{pCi} / 1 ; \mathrm{C}_{\mathrm{g}}$ is gross counts observed in the counting interval; $\mathrm{C}_{\mathrm{b}}$ is background counts that would be expected during the same counting interval; $Y$ is cell sensitivity for radon in secular equilibrium with its alpha-emitting daughters, determined for the pressure at which the cell was counted, in $\mathrm{cph} / \mathrm{pCi} / 1$; $\lambda$ is $0.007554 / \mathrm{h}$ (based on a radon half-1ife of 3.8235 days [16]); $t_{1}$ is elapsed time from the sample fill to the beginning of the counting interval, in hours; and $t_{2}$ is elapsed time from sample fill to the end of the counting interval, in hours. The cell sensitivity, $Y$, is discussed in more detail in Section 4.2 .

An adequate approximation when counting a sample for several hours or less is expressed by the equation

$$
R n_{0}=\frac{\left(C_{g}-C_{b}\right) / T}{Y e^{-\lambda\left(t_{1}+T / 2\right)}}
$$

where $T$ is the counting interval in hours $\left(t_{2}-t_{1}\right)$, and the other parameters are as defined above.

\subsection{DATA INTERPRETATION}

For each highly ventilated structure, two radon activities are determined since each structure is evaluated on two different days. These calculated activities should be converted from $\mathrm{pCi} / 1$ to working levels (WL) as outlined in Section 4.3.2.2. Apply the following criteria to these two results, and use the value obtained from the applicable set of criteria as the average RDC estimate if such an estimate is at least twice the value obtained by a long-term integrated sampling method:

- If the radon grab results differ by less than 30 percent of their mean, use their mean as the average RDC estimate.

- If the radon grab results differ by more than 30 percent of their mean and the radon grab results are either both greater than or both less than the radon-daughter-concentration standard, use their mean as the average RDC estimate.

- If the radon grab results differ by more than 30 percent of their mean and bracket the standard, obtain a third radon grab evaluation sometime during the months of October through March and use the mean of all three results as the average RDC estimate. (Three measurements are not recommended initially because of the cost and effort involved in each measurement.) 
Appendix A presents examples of data interpretation.

\subsection{CALIBRATION}

\subsection{COUNTING SYSTEM PLATEAU AND DAILY CALIBRATION CHECK}

The scaler, detector, and high-voltage cable that make up the counting system should be calibrated together and remain together as one unit. Any equipment substitutions require recalibration of the system.

\subsubsection{Determination of High-Voltage Plateau}

Each unit should be operated at the high-voltage (HV) setting that combines maximum stability, good counting efficiency, and low background counts. This optimum setting is determined by incrementing the high voltage and plotting on separate curves the resultant counts for a check source, a radon-filled cell counted after a 4-hour ingrowth (corrected for decay), and the empty detector. Because the different geometries of the check source and the cell produce curves ith different shapes, the operating voltage should be selected on the plateau (the region of minimum slope) of the cell curve, before the upswing in background curve. Ideally, the slope of the plateau will not exceed 2 percent per 100 volts [10]. An example of a set of counting curves is shown in Figure 5; the selected voltage is indicated by an asterisk.

Each counting system should be plateaued before being used, after repairs, or at least once a year. Then the check source should be counted at the selected high-voltage setting and for a predetermined time: 10 minutes is an acceptable count time. Counting is performed in the following manner:

1. Center the zinc sulfide mylar screen on the PM tube with the dull side up. Place the active side of the source down on the screen. Replace the 1 ight-tight cover, wait 2 minutes, and begin the count.

2. Repeat the count eight more times. Determine the mean and standard deviation of the nine counts. 


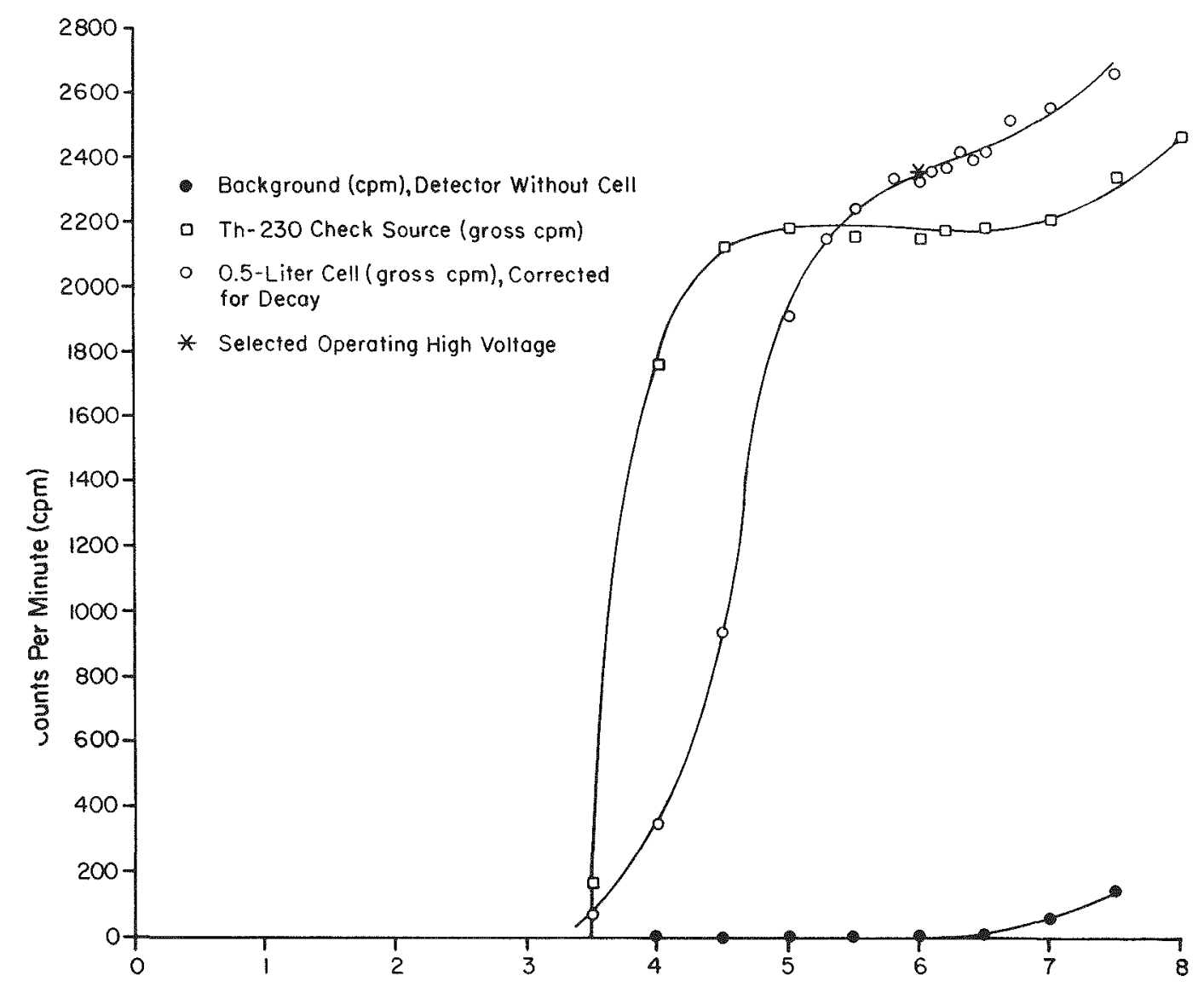

High-Volfoge Potentiometer Setting

Figure 5. High-Voltage Counting Curves for Determination of System P1ateau and Selection of Operating High Voltage (from unpublished data collected by J. L. George) 


\subsubsection{Daily Calibration Check}

The check source should be run once daily in every counting system prior to use. The daily check-source count is then compared with the mean value derived in Step 2 above to verify proper operation of the system. If the counts are not within plus-or-minus two times the square root of the mean value (the 95 percent confidence interval based on Poisson statistics), count the check source again. If the counts are still abnormal, check that the HV and other settings are correct. Do not proceed until the problem is identified and corrected.

\subsection{CELL CALIBRATION}

An accurate sensitivity (Y) should be determined for each scintillation cell used. Batch calibration of cells is not recommended because of the wide range of sensitivities that may occur in a group of cells. (The sensitivities for the 0.5-1iter ce11s used by the Technical Measurements Center range from 1.9 to $2.5 \mathrm{cpm} / \mathrm{pCi} / 1$.$) There are two possible approaches to this$ problem. The first requires that an agency establish its own calibration facility. Alternatively, cells and counting equipment may be brought to the DOE Technical Measurements Center in Grand Junction, Colorado, for simultaneous comparison with TMC cells, which have been calibrated using National Bureau of Standards (NBS) radium-226 solutions. The latter is the simpler approach; setting up a radon calibration 1 aboratory is a complex process.

The discussion contained herein is not intended to be a complete description of the calibration process. Rather, it addresses some of the problems that will be encountered in setting up a radon de-emanation system. By consulting the literature regarding different radon calibration systems $[5,10,11,12,13,14]$, insight may be gained with respect to available alternatives. The Technical Measurements Center should al so be consulted before a remedial action contractor establishes a radon calibration facility.

\subsubsection{Determination of Ce11 Volume}

The volume of each scintillation cell should be determined accurately and nondestructively. Vapor-pressure effects should be accounted for if a bubble tube, or other method involving water, is used to measure the volume indirectly. 


\subsubsection{Radium Standards}

The NBS radium solutions should be quantitatively transferred into bubble tubes and diluted to fill no more than half the bubble-tube volume. Each solution should then be thoroughly purged to establish a base time for ingrowth calculations. The solutions should be stored securely between calibration runs, and accurate records kept of the use of each solution. Extreme care should be taken to avoid excessive bubbling or other loss of a solution since any loss will invalidate the use of the solution as a standard. Correction factors should be determined for the percentage of radon de-emanated from solution if the air bubbled through the solution is less than ten times the volume of the solution, as when calibrating 0.1-1iter scintillation cells. Each cell should be leak-tested before bubbling, and pressurized to standard pressure after bubbling.

Care is essential at every step in the procedure for determining precise sensitivities and, therefore, accurate radon measurements. The NBS standards are certified to approximately \pm 1.5 percent. Reasonably achievable average uncertainties are in the $r$ ange of 5 to 10 percent.

\subsubsection{Verification of Cell Calibration}

The calibration of all cells should be monitored annully to verify that the sensitivity of each cell has not changed. First. cells should be leak-tested and background-counted as described in section 3.1. Then all cells should be filled fom the same radon source. Flow-through-type cells can be filled by punping the filtered sample through the cells which are arranged in series, allowing enough time for at least ten air exchanges through the entire chain. Lucas-type cells can be filled by simultaneous grab.

Cells should be counted at the desired pressure after they have reached equilibrium, and a radon activity calculated for each cel1 using its current sensitivity. A cell should be recalibrated if its calculated activity differs from the mean activity by more than 10 percent. Also, a Lucas-type cell should be recalibrated each time its interior is reconted ith new phosphor.

\subsection{FIELD CALIBRATION}

Calibration is performed for each community by correlating radon grab measurements collected under standard maimized conditions 
with estimates of the average radon-daughter concentration obtained under occupied conditions using a long-term integrating method. A separate correlation should be performed for each community since the working-level ratio (WLR) varies widely. (The working-level ratio is the ratio of the measured working level to the working level that would be present if radon was in equilibrium with its daughters.) Results of a survey of 10,000 Canadian homes demonstrated that the average WLR in 14 cities ranged from 0.19 to 0.67 [15].

\subsubsection{Structure Selection}

Structures selected for the correlation should have ventilation rates representative of the average for the particular communitys structures with high ventilation rates should not be included. A1so, the study group should represent a wide range of radondaughter concentrations, as indicated by the long-term integrated results. For purposes of the correlation, radon grab samples should be collected under the standard maximized conditions detailed in Section 3.2 at the same location in the same room as the long-term integrated data were collected. The radon grab data need not be acquired during the course of long-term integrated evaluation: in fact. several years may elapse between long-term integrated sampling and the collection of radon grab data in a structure, provided the structure has not been remodeled. A change of occupants is also acceptable. A minimum of 50 data pairs should be collected. (In the case of small communities where collection of this volume of data is impossible, consult the Technical Measurements Center for additional guidance.) The calibration factor derived from the study-group data is applied to all radon grab measurements obtained in the community.

\subsubsection{Example of Field Calibration}

The calibration process is best illustrated by an example. The Colorado Department of Health has accumulated measurement data obtained using both radon grab and Radon Progeny Integrating Sampling Unit (RPISU) methods during the course of the Grand Junction Remedial Action Program. The RPISU data were acquired during the routine evaluation of structures before and/or after remedial action. The radon grab samples were obtained under standard maximized conditions by ARIX, the architectural/ engineering firm under contract to the Colorado Department of Health. A tabular comparison of these data is presented in the Protocol and in the evaluation report $[1,2]$. 
4.3.2.1 Lor Conversion of Calibration Data. Lognormal distributions are expected for the RPISU and radon $\mathrm{grab}$ data and their error terms [2]. However, regression analysis and statistical tests require normal distributions of values and deviations. Therefore, if the data are tested and found to be 10 gnormally distributed, they must be converted to $10 \mathrm{~g}$ values and the regression analysis performed on the $10 \mathrm{~g}$ values (see Figure 6).

4.3.2.2 Conversion of Grab-Sample Results. The radon grabsample results must be converted back into linear values [2]. The regression line in the example would be converted back to RPISU $=0.00708$ ( $\operatorname{Rad} 0 n \mathrm{Grab}) 0.747$ and used to estimate working levels from radon grab measurements. For example, a radon grab sample of $10.12 \mathrm{pCi} / 1$ is converted to $0.040 \mathrm{WL}$.

\subsection{QUALITI ASSURANCE AND CONTROL}

\subsection{GENERAL}

The quality-assurance measures described herein are designed such that all work performed in association with radon grab sampling will meet two objectives. The first objective is to obtain the highest quality results possible. The second is to sufficiently document the work performed to permit future review by independent but knowledgeable persons. In essence, the latter objective is accomplished by recording raw data together with enough pertinent information (i.e.., what, why, where, etc.) to permit evaluation of the methods employed and verification of the results reported. The quality-assurance requirements described in the sections that follow assist in meeting the above objectives.

\subsection{PERSONNEL AND ORGANIZATION}

Identification of the people responsible for various portions of the work and the organizational relationships among those people should be included in the documentation of the work. All personnel involved in the collection and analysis of samples should be properly trained: documentation of such training or of appropriate prior qualifications should also be part of the work records. 


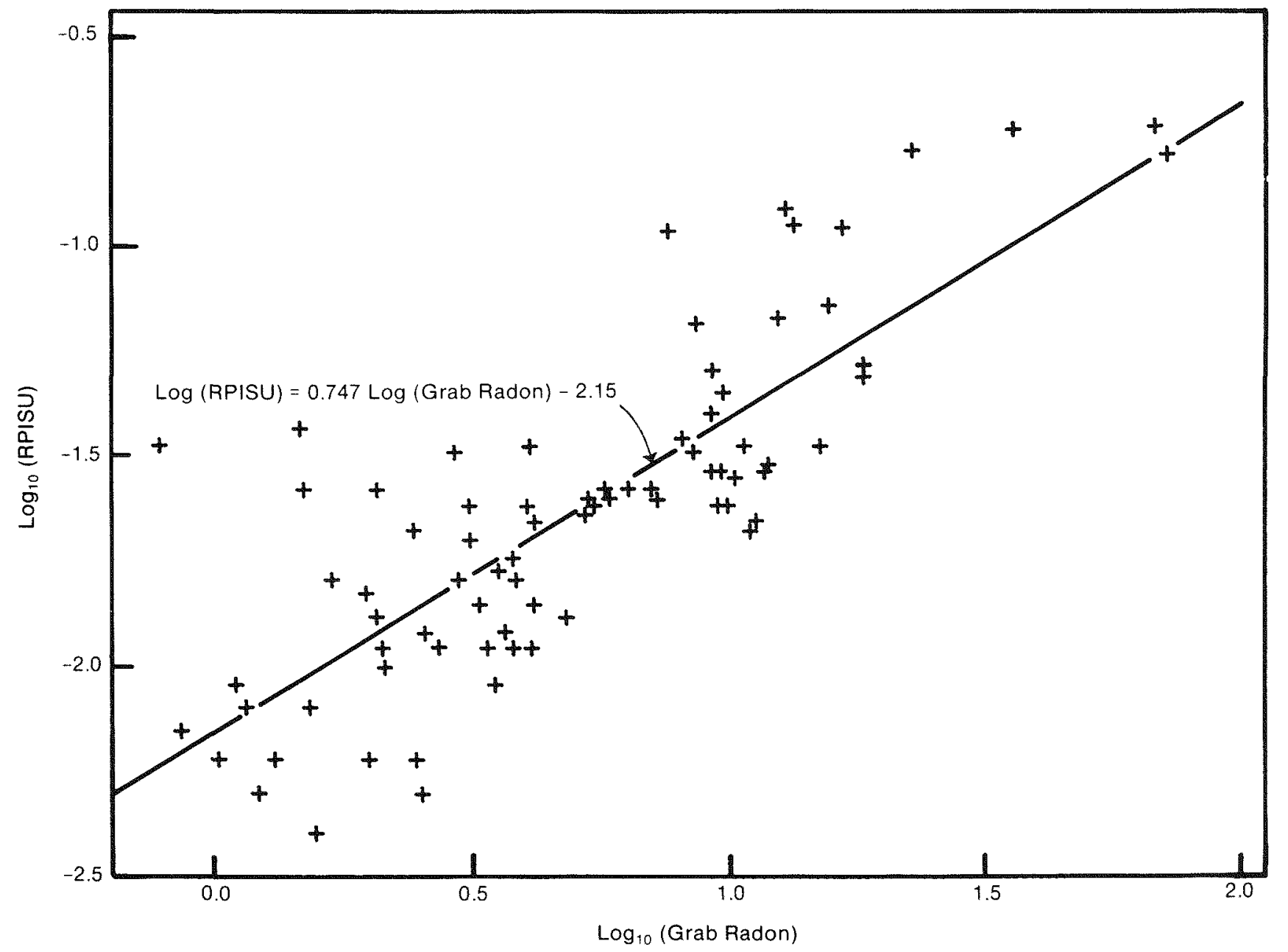

Figure 6. Log of RPISU RDC Versus the Log of Grab Radon for Those Structures with Norma1 Grab Radon/RPISU Ratios (taken from Langner and Pacer, [1]) 


\subsection{PROCEDURES}

Written procedures that accurately detail the conduct of all aspects of the work should be included in the documentation of the work. Any deviation from these procedures should also be recorded. To ensure that current and correct procedures are used, the guidelines 1 isted below should be followed:

- Procedures should be formally reviewed and approved by the customer before the start of work.

- Procedures should be controlled documents.

\subsection{SAMPLE AND DATA COLLECTION}

The collection of samples and the generation of results should be adequately documented.

\subsubsection{Documentation of Sample Collection}

Documentation of sample collection should include the following information:

- Occupant Name

- Room Samp1ed

- Location Code Number

- Time and Date of Sampling

- Operator Name

- Weather Data

\subsubsection{Documentation of Ce11-Background Data}

Documentation of cel1-background data should include the following information:

- Date of Ce11-Background Counting

- Date and Results of Leak Test

- Counting System Used 
- Check-Source Counts

- Cel1 Number

- Background Counts

- Operator Name

\subsubsection{Documentation of Sample Results}

Documentation of the results generated from the sample data should include the following information:

- Date of Sample Counting

- Counting System Used

- Check-Source Counts

- Start Time of Cel1 Counts

- Gross Counts

- Sensitivity Used

- Ca1culated Radon Activity

- Operator Name

\subsubsection{Documentation of Genera1 Quality-Assurance Tasks}

The accuracy of the radon grab measurements should be verified by performing the following tasks:

- Acquisition of daily check-source counts.

- Annual recalibration of all scintillation cells.

- Annual cross-comparison ith the Technical Measurements Center or another appropriate laboratory.

- Acquisition of duplicate samples for at least 5 percent of the routine samples to verify that the average coefficient of variation is not greater than 15 percent. 
Performance of each of the above tasks, including results obtained, should be documented in the work records.

\subsection{INCIDENT REPORTING AND CORRECTIVE ACTION}

A system for reporting nonconformances and/or incidents that affect the quality of work should be established. In addition, a mechanism for conducting corrective action should be set up.

\subsection{RECORDKEEPING}

A complete set of the records of the work, as detailed above. should be maintained and protected from loss or damage.

\subsection{QUALITY-AS SURANCE AUDITS}

Audits should be performed routinely to verify and document compliance with the quality-assurance requirements detailed herein.

\subsection{ACKNOWLEDGMENTS}

I am grateful for the support and helpful comments of Mary Gerry White. TMC Program Manager during the preparation of this manual, Office of Remedia1 Action and Waste Technology: Larry Ba11, Project Officer. Grand Junction Projects Office: and John R. Duray, Project Manager, Technical Measurements Center. I would also like to thank all the other people who reviewed this docament: Some submitted written comments; others attended the TMC workshop. 'Methods for the Estimation of Indoor Radon-Daughter Concentration,' held in Grand Junction, Colorado, on 27-29 July 1983, and verbal1y shared their ideas, concerns, and experiences. 


\subsection{REFERENCES}

[1] Langner, G. H., Jx., and J. C. Pacer, 1986. Protocol for the Estimation of Average Indoor Radon-Daughter Concentrations. GJ/TMC-09, U.S. Department of Energy, Technical Measurements Center, Grand Junction, Colorado (Draft).

[2] Langner, G. H., Jr., J. C. Pacer, V. G. Johnson, and M. A. Gillings, 1983. Evaluation of Methods for the Estimation of Indoor Radon-Daughter Concentrations for Remedial Action Programs, GJ/TMC-04, U.S. Department of Energy, Technical Measurements Center, Grand Junction, Colorado.

[3] Bres1in, A. J., 1977. 'Methods Used by HASL for Ambient Radon Studies,' in Radon Workshop-February 1977, HASL-325, Heal th and Safety Laboratory, New York.

[4] George, A.C., 1976. 'Scinti11ation F1asks for the Determination of Low Leve1 Concentrations of Radon,' in Proceedings of Ninth Midyear Health Physics Symposium. Denver, Colorado, February, 1976.

[5] Beckman, R. T., 1975. Calibration Procedures for Radon and Radon-Daughter Measurement Equipment, Informational Report 1005, U.S. Department of the Interior, Mining Enforcement and Safety Administration.

[6] Lucas, H. F., 1957. 'Improved Low-Level Alpha Scintillation Counter for Radon,' in Review of Scientific Instruments, Vo1. 38, p. 680 .

[7] Lucas, H. F., Jr., 1964. 'A Fast and Accurate Survey Technique for Both Radon-222 and Radium-226,' in The Natural Radiation Envixonment. University of Chicago Press. Chicago.

[8] Kno11, G. F., 1979. Radiation Detection and Measurement, John Wiley and Sons, New York.

[9] Ho1ub, R. F., and R. F. Drou11ard, 1977. 'Evaluation of Various Radon-Daughter Methods,' in Workshop on Methods for Measuring Radiation In and Around Uranium Mi11s, Atomic Industria1 Forum, Inc., Washington, D.C.

[10] American Society for Testing and Materials, 1977. 'Tentative Test Method for Radium-226 in Water,' in Annual Book of ASTM Standards. Part 31-Water. American Society for Testing and Materials, Easton, Maryland. 
[11] Ingerso11, J. L. , 1980. Operating Instructions for LBL Radon Measurement Facilities, LBL-11097, Lawrence Berkeley Laboratory, University of California, Berkeley.

[12] Johns, F. B., P. B. Hahn, D. J. Thome', and E. W. Bret thauer (eds.), 1979. 'Determination of Radon-222 in Air, Water, and Natural Gas,' in Radiochemical Analytical Procedures for Analysis of Environmenta1 Samples, EMSL-LV-0539-17, prepared under Memorandum of Understanding EY-76-A-08-0539, EPA Fnvironmental Monitoring and Support Laboratory, Las Vegas, Nevada.

[13] Thatcher, L. L., V. J. Janzer, and K. W. Edwards, 1976. 'Radium-226, Dissolved Radon Emanation Method,' in Techniques of Water Resources Investigations of the United States Geological Survey, Methods for Determination of Radioactive Substances in Water and Fluvial Sediments, U.S. Government Printing of ice, Washington, D.C.

[14] Misaqi, F. L,. 1975. Monitoring Radon-222 Content of Mine Water, Informational Report 1026 , U.S. Department of the Interior, Mining Enforcement and Safety Administration.

[15] McGregor, R. G., P. Vasudev, F. G. Letourneau, R. S. McCullough, F. A. Prant1, and H. Taniguchi, 1980.

'Background Concentrations of Radon and Radon Daughters in 'anadian Homes,' Health Physics, Vo1. 39, pp. 285-289.

[16] Lederer, C. M., and V. S. Shirley, (eds.), 1978. Table of Isotopes, Seventh edition, John Wiley and Sons, New York. 


\section{Appendiz A}

AN EXAMPLE OF A PROCEDURE FOR OBTAINING RADON GRAB MEASUREMENTS USING A SCINTILLATION CELL

This appendix presents an example of a step-by-step procedure that can be used with scintillation cells when performing radon grab sampling in support of DOE remedial action programs. The procedure outlines the steps to be followed for a single radon determination. Two such determinations are conducted on two different days to evaluate a structure (see Section 3.4).

\section{A.1 BACKGROUND COUNTING OF CELL}

1. Count check source.

2. Leak test Lucas-type col1. Pressurize coll to standard pressure (see Section A.5).

3. Place cell in detector: replace light-tight cover.

4. Wait 2 minutes. Acquire three 10-minute counts.

5. Record date, counting-system number, check-source counts, col1 number, and background counts.

6. Bring cell to ambient pressure by opening and closing a valve.

\section{A.2 SAMPLE COLLECTION}

The following standard conditions should be maintained for a period of 12 hours prior to sample colloction as well as during collection:

- A11 doors and windows closed.

- All vontilation systems turned off.

- Surface winds 1 ess than 10 miles per hour.

- Stable atmospheric pressure.

- Building unoccupied, if possible.

The sample should be collocted between 6:00 and 8:00 a.m. 


\section{A.2.1 Sample Collection for Lucas-Tyoe Ce11s}

1. Evacuate cell to 500 microns prior to leaving the 1aboratory.

2. Assemble filter holder.

3. Pump sample air through filter assembly.

4. Connect filter assembly to cell.

5. Open cell valve for 10 seconds. Record time of fill.

\section{A.2.2 Sample Collection for Flow-Through Ce11s}

1. Assemble filter holder.

2. Connect one cell valve to filter assembly and other valve to pump.

3. Open both cell valves. Start pump and stopwatch. Pul1 air through cell long enough to allow ten air exchanges.

4. Turn off pump and close cell valves. Record time of fill as time at which pump is turned off.

5. Wipe cell with antistatic spray.

6. Record date, cell used, location of sample, time of fill, operator name, ventilation conditions, and meteorologic conditions.

\section{A.3 SAMPLE COUNTING}

1. Wait 4 hours after collecting the sample before counting the ce11.

2. Bring cell to standard pressure (see Section A.5).

3. Run check source on counting system.

4. P1ace cell in detector; replace light-tight cover.

5. Wait 2 minutes. Acquire three valid, consecutive, 10-minute counts.

6. F1ush ce11 with radon-free gas, and store at ambient pressure. 


\section{A.4 DATA REDUCTION}

Calculate the radon activity of the sample using the equation

$$
R n_{0}=\frac{\left(C_{g}-C_{b}\right) / T}{Y e^{-\lambda\left(t_{1}+T / 2\right)}}
$$

where $R n_{0}$ is the radon activity at the time of the sample collection $t ; C_{g}$ is the number of gross counts observed during the counting interva1: $C_{b}$ is the number of background counts that would be expected during the same counting interval; $Y$ is the cell sensitivity for radon in secular equilibrium with its alphaemitting danghters, determined at standard pressure, in $\mathrm{cph} / \mathrm{pCi} / 1 ; \lambda$ is $0.007554 / \mathrm{h}$ (based on a radon half-1ife of 3.8235 days [16]): $t_{1}$ is the elapsed time from sample fill to the beginning of the counting interval, in hours: and $T$ is the counting interval in hours.

This equation does not account for any radon that may be introduced by pressurizing the cell with aged air. The activity of the small amount of air that is used for pressurization purposes is known to be negligible. Reported radon activities in 12 cylinders having a capacity of 220 cubic feet at 2000 pounds per square inch (psi) range from $5 \times 10^{-4}$ to $5 \times 10^{-3} \mathrm{pCi} / 1$ [6]. The radon activity of TMC cylinders is monitored routinely and is in this range. However, the radon activity in a cylinder could conceivably be significant. especially at low cylinder pressures. Therefore, the radon activity of each cylinder should be monitored as suggested in Section A.5, and corrections applied to calculated sample activities when appropriate.

\section{A.5 DATA INTERPRETATION}

After two radon grab measurements have been made, convert the results from radon activity to radon-daughter concentration using the conversion equation determined for the community in question. (For example, from the equation given in Section $4.3,4 \mathrm{pCi} / 1$ radon converts to 0.0199 WL radon-daughter concentration for the Grand Junction area.) Apply the following criteria to these two results, and use the value obtained from the applicable set of criteria as the average $\mathrm{RDC}$ estimate if such estimate is at least two times the value obtained by a long-term integrated sampling method:

- If the radon grab results differ by less than 30 percent of their mean, use their mean as the average RDC estimate. 
- If the radon grab results differ by more than 30 percent of their mean and the radon grab results are either both greater than or both less than the RDC standard, use their mean as the average RDC estimate.

- If the radon grab results differ by more than 30 percent of their mean and bracket the standard, obtain third radon grab evaluation sometime during the months of October through March and use the mean of al1 three results as the average RDC estimate.

The following hypothetical situation ill illustrate the importance of data interpretation when maing indoor RDC measurements.

Annua 1 average radon-daughter-concentration (RDC) measurements were made at as station in Grand Junction, Colorado, for the Department of Energy's Uranin Mi11 Tailings Remedial Action Program. Using the RPISU method, the annual average RDC was determined to be $0.015 \mathrm{WL}$.

Since the gas station is considered to be highly ventilated, a series of radon grab samples as obtained using the procednre outlined in this manual. The results were converted from radon concentration in $\mathrm{pCi} / 1$ to radon-daughter concentrations in WL using the equation RPISU $=0.00708 \mathrm{a} \mathrm{Rn} 0.749$. Grab-sample results and their equivalent RDC value in working levels (WL) are presented in Table $\mathrm{A}-1$.

Tab1e A-1.

Hypothetical Resuits of Grab Sampling at the Grand Junction Gas Station

\begin{tabular}{ccc}
\hline Sample & $\begin{array}{c}\text { Rn Grab Sample } \\
(\mathrm{pCi} / 1)\end{array}$ & $\begin{array}{c}\text { Equivalent RDC } \\
\text { (WL) }\end{array}$ \\
\hline A & & \\
B & 7.0 & 0.030 \\
C & 8.8 & 0.036 \\
D & 6.3 & 0.028 \\
E & 3.5 & 0.018 \\
& 4.5 & 0.022 \\
\hline
\end{tabular}

Based on the hypothetical results presented in Table A-1, if the radon evaluation consisted of samples $A$ and $B$, the first criterion 1 isted above for determining average RDC would apply. 
The average of samples $A$ and $B$ is $0.033 \mathrm{WL}$, which is more than twice the 0.015-WL estimated RDC determined by the RPISU method. Therefore, 0.033 WL would be the value used to compare to the indoor RDC standard of 0.02 WL.

However, if the radon evaluation consisted of samples $C$ and $D$, the third criterion listed above would apply, since the results bracket the standard ( $0.02 \mathrm{WL})$ and they differ by more than 30 percent of their mean. Thus, another grab sample is required to complete the radon evaluation. Using sample $E$ as the additional grab sample, the mean RDC determined from the results of samples $C, D$, and $E$ is 0.023 WL. The average RDC based upon grab samples C, D, and $E(0.023 \mathrm{WL})$ is not more than twice the 0.015 -WL. estimated RDC determined by the RPISU method. Therefore. al though the average RDC determined by the radon grab method is greater than the indoor RDC standard of $0.02 \mathrm{WL}$, the RPISUestimated RDC value would be used to compare to the standard since the radon-grab estimate is not more than twice that of the RPISU method.

\section{A.6 CELL PRESSURIZATION}

1. Connect cell to barometric assembly. Valves 1, 2, 3, 5, and 6 are closed (see Figure $A-1$ ).

2. Open valve 1. Evacuate the 1 ines to 1 ess than $1 \mathrm{mmHg}$.

3. Shrt off vacun at valve 1 .

4. Open valves 5 and 6 . Adjust valve 4 as needed to fill lines to standard pressure with aged air.

5. Open valve 2: bleed aged air until standard pressure is reached.

6. Close valve 2 .

7. Close valve 5 .

8. Disconnect cell.

An empty cell should be routinely filled to the standard pressure with aged air and counted at equilibrium to determine the radon activity of the aged air. The activity may increase as the pressure in the cylinder decreases [6]. Samples should therefore be taken at cylinder pressures of $100,80,60,40$, and 20 percent of cylinder capacity. 


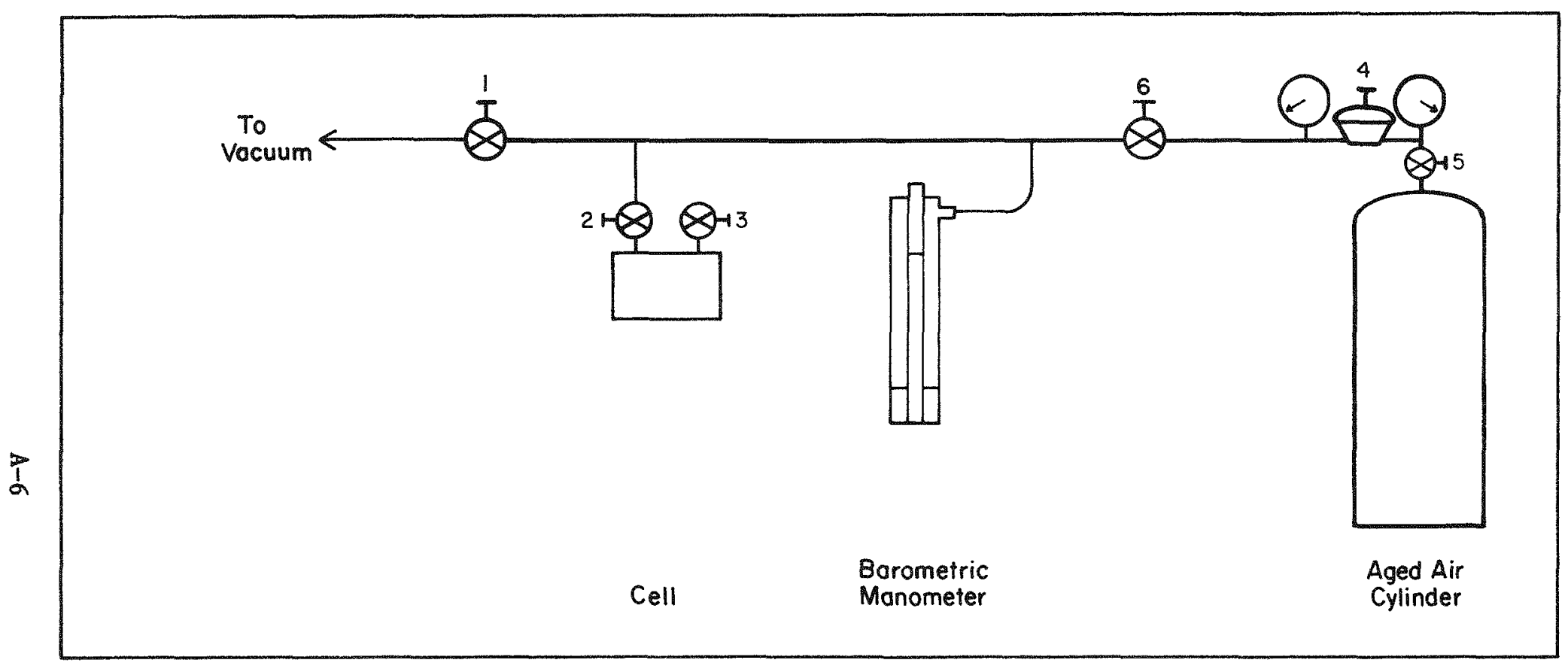

Figure A-1. Schematic of Barometric Assembly 


\author{
PUBLICATIONS \\ Issued by \\ TECHNICAL MEASUREMENTS CENTER \\ Bendix Field Engineering Corporation \\ for \\ U.S. Department of Energy \\ Office of Remedial Action and Waste Technology \\ Idaho Operations office \\ Grand Junction Projects Office \\ April 1986
}

Number

GJ $/$ TMC $-01 * f$

$\mathrm{GJ} / \mathrm{TMC}-02$

GJ / TMC-03*

GJ / TMC-0 4*

GJ $/ \mathrm{TMC}-05^{*}$

GJ/TMC-06*

GJ /TMC -07 *

\section{Title (Authors)}

Field Calibration Facilities for Environmental Measurement of Radium. Thorium, and Potassium. (D. C. George and L. Knight)

Review of Selected DOE Remedial Action Field Measurement Procedures for the Summer of 1982 . (TMC Staff)

Abbreviated Tota1-Count Logging Procedures for Use in Remedial Action. (D. C. George and R. K. Price)

Evaluation of Methods for the Estimation of Indoor Radon Daughter Concentrations for Remedial Action Programs. (G. H. Langner, Jr., J. C. Pacer, V. G. Johnson, and M. A. Gillings)

Feasibility Study of the Prompt Pb-214, Bi-214 Gamma Method for Determining Radon Migration Through Tailings. (L. R. Stieff, The Stieff Research and Development Co., Inc., Kensington, Maryland)

Surface Gamma-Ray Mea surement Protocol. (S. J. Marutzky, W. D. Steele, and B. N. Key)

Procedures for Field Chemical Analyses of Water Samples. (N. Korte and D. Ealey)

* Available from

Nationa 1 Technical Information Service U.S. Department of Commerce 5285 Port Royal Road Springfield, Virginia 22161 $703 / 487-4600$

tTo be updated. 


\author{
PUBL ICATIONS \\ Is sued by \\ TECHNICAL MEASUREMENTS CENTER \\ (cont inued)
}

Number

GI/TMC-08*

2nd Edition

GJ/TMC-10*

GJ/TMC-11*

GJ/TMC-12*

GJ/TMC-13*

GJ/TMC-14*

GJ/TMC-15*

GJ /TMC -16 *

GJ /TMC-17*

\section{Title (Authors)}

Procedures for the Collection and Preservation of Groundwater and Surface Water Samples and for the Installation of Monitoring Wells: Second Edition. (N. Korte and P. Kear1)

Development of Solid Radium-226 Reference Materials. (R. B. Chessmore and P. R. Engelder)

Procedure Manual for the Estimation of Average Indoor Radon-Daugher Concentrations Using the Radon GrabSamp1ing Me thod. (J. L. George)

Procedure Manual for the Estimation of Average Indoor Radon-Daughter Concentrations Using the Radon Progeny Integrating Sampling Unit (RPISU) Method. (G. H. Langne $r_{,} \mathrm{J}_{\mathbf{r}}$ )

Procedures for Sampling Radium-Contaminated Soils. (H. L. F1 eischhauex)

Procedures for Reconnaissance Stream-Sediment Sampling. (H. L. F1 eischhauer and P. R. Engelder)

A Feasibility Study of the Use of Nuclear-Emulsion Techniques in the Study of Drill Core and Water Samples from the Montice110 Mi11, Montice110, Utah. (L. R. Stieff, The Stieff Research and Development Co.. Inc., Kensington, Maryland)

Test and Evaluation of Selected Instruments for Surface Gamma-Ray Mea surements. (B. N. Key)

Calibration-Pad Parameter Assignments for In-Situ Gamma-Ray Measurements of Radium, Thorium, and Potassium. (D. C. George, E. F. Novak, and R. K. Price)

\footnotetext{
* Available from

National Technical Information Service

U.S. Department of Commerce

5285 Port Royal Road

Springfield, Virginia 22161

703/487-4600
} 


\section{PUBLICATIONS \\ Issued by \\ TECHNICAL MEASUREMENTS CENTER \\ (continued)}

Number

$\mathrm{GJ} / \mathrm{TMC}-18$ *

GJ /TMC-19*

GJ $/$ TMC-20

GJ/TMC-22*

GJ /TMC-23

GJ $/ T M C-27$ *

\section{Title (Authors)}

Operating Manual for the Radon-Daughter Chamber. (G. H. Langner, Jr., and T. Ne1 son)

Laboratory Intercomparison of Analytical Results on Samples Contaminated by Uranium Mill Tailings.

(N. Korte, M. Hollenbach, and S. Donivan)

Radon-Daughter Chamber Instrumentation System Reference kanual. (L. Johnson and R. Showalter)

Development of Solid Thorium-232 Reference Materials. (P. R. Engelder, S. Donivan, and R. B. Chessmore)

Gamma-Ray Instrument Calibration Comparison Workshop. (W. D. Steele, D. C. George, and J. L. Burnham)

Assessment of Mobile Gamma-Scanning Van Activities in Edgemont, South Dakota. (U.S. Department of Energy Task Force)

* Available from

National Technical Information Service

U.S. Department of Commerce

5285 Port Roya1 Road

Springfield, Virginia 22161 